\title{
E-Payment Technology Effect on Bank Performance in Emerging Economies-Evidence from Nigeria
}

\author{
Saidi Atanda Mustapha \\ Department of Economics, Finance and Accounting, Bells University of Technology, Benja Village, Ota 23401, \\ Nigeria; satanda4345@gmail.com \\ Received: 3 August 2018; Accepted: 27 August 2018; Published: 21 September 2018

\begin{abstract}
The development of the financial sector has been a major growth driver in all economies, especially in emerging economies. Part of the financial innovations in the sector in recent times is the electronic payment system. Several studies in developed countries have substantiated the positive transformation of this financial innovation. This paper therefore contributes to this debate with three research innovations: first, it adopts a new measure of bank performance-the sortino index; second, it relates market risk exposure of banks to electronic payment technologies; and third, it controls for "without effects" of these innovations on bank performance using interacting dummies. Based on the time dimensional and panel least square models, it finds that bank performance increased after the adoption of electronic payment technologies. Finally, its findings show that bank performance contradicts autoregressive and random walk processes and thus implies that investors should not be disturbed about previous bank performances but concerned about current bank resources.
\end{abstract}

Keywords: electronic payment platforms; electronic banking; point of sales technology; Automatic Teller Machine (ATM) technology; sortino ratio

\section{Introduction}

Contributions of the financial sector to growth of an economy in undeveloped, developing, emerging and developed markets have been given astounding remarks in the literature. [1-6]. In Nigeria, the general consensus of studies is that the financial sector propelled economic growth through various channels $[5,7]$. Activities of the Nigerian financial sector depends largely on deposit money banks. Hence, bank performance is crucial to financial sector development. The evolution of electronic banking platforms/technologies came to existence in 2012, following the directives of the Central Bank of Nigeria to promote cashless systems. Most banks commenced the implementation of the instruction almost immediately with the pilot study held in Lagos State, Nigeria. Before the end of the year, the thirty-five States of the Federation and the Federal Capital Territory had adjusted to the cashless policy.

The banking sub-sector of the finance industry in Nigeria has been the main driver of growth and development in the industry. This can be buttressed with the impressive performances of the sub-sector within the sector and on the Stock Exchange market. Banks focus on acceptance of deposits and settlements of financial commitments. The electronic banking operations concentrates on the payment aspect of banking activities, and therefore, most technology innovations are to support payment activities. In recent times, electronic payment innovations have brought about several electronic payment channels and subsequent establishments of financial technology companies. The widely used e-payment technologies in the country are Automatic Teller Machine (ATM), Point of Sale (POS) Technology, Mobile Money Transfer (MMT) Technology and Online Money Payment (WEB) Technology according to Nigerian Inter-Bank Settlement System report. Shares of these electronic payment technologies have increased continuously since inception (see Table 1). The rising shares 
and high rate of adoption for settlement of payments have exposed customers to more risks such as internet fraudsters and incomplete transactions, among others.

Table 1. Shares of E-Payment Technologies (in \%).

\begin{tabular}{cccccccc}
\hline Year & Cheque & ATM & POS & NIP & NEFT & Mobile & Online \\
\hline 2012 & 15.54 & 18.48 & 16.67 & 17.70 & 14.89 & 19.94 & 10.27 \\
2013 & 14.42 & 24.28 & 30.97 & 26.16 & 14.83 & 29.01 & 14.32 \\
2014 & 19.40 & 7.54 & 6.85 & 9.28 & 18.06 & 3.67 & 15.95 \\
2015 & 16.61 & 13.76 & 9.88 & 11.90 & 16.24 & 10.92 & 16.58 \\
2016 & 16.93 & 15.99 & 16.08 & 16.30 & 17.25 & 15.90 & 20.78 \\
2017 & 17.10 & 19.95 & 19.55 & 18.67 & 18.73 & 20.57 & 22.10 \\
\hline
\end{tabular}

Source: Computed by the author. Underlying data are from the Nigerian Inter-Bank Settlement System (NIBBS) (2017). Note: Automated Teller Machine (ATM); Point of Sales (POS) Technology; Instant Payment (NIP); National Electronic Fund Transfer (NEFT).

With this development, bank performance in terms of profitability, expected returns and risk exposure have generated mixed feelings. On one hand, most deposit money banks in emerging economies possess increased profit without sustainable growth [8]; on the other hand, the adoption of electronic payment technologies have reduced the actual returns of bank stakeholders and raise their risk exposure $[9,10]$. More so, the introduction of electronic payment technologies has brought about change in the business models of banks in Nigeria. This has increased the cost of operation in the transition period. Up until now, some of the deposit money banks spent a substantial amount to support developments in electronic payments technologies and to also remain competitive with the Financial Technology (FinTech) firms in the country.

Fundamental issues of achieving sustainable business growth and rising operational costs in the banking sub-sector have resulted in the pursuit of providing responses to the following research questions. First, are there relationships among bank profitability, performance and risk exposure? The main reason for this question is to ascertain which of the goals will be an optimal strategy for the banking sub-sector, especially in the current period of rising e-payment technology innovation. Second, what is the effect of the electronic payment technologies used on bank performance and risk exposure? Third, do banks achieve stable growth after the adoption of the electronic payment technologies? It is essential to research on the effects of electronic payment technology innovation on the performance of the banking sub-sector considering the cross sectional and time dimensional events.

This paper is arranged in five sections. The introduction is contained in Section 1, while Section 2 consists of the related literature. The Section 3 describes the method and Section 4 presents and discusses the findings. Section 5 concludes the research.

\section{Related Literature}

One of the most frequently used measures of performance is profitability [11-13]. Meanwhile, studies have divided the measure of bank profit into two. First, studies have used return on asset (ROA), return on equity (ROE), and capital and level of exposure to risk. These variables are internal factors that influence the profitability in banks and therefore, this division is the internal measure. Empirically, Berger found that large banks cannot increase savings significantly through increasing insize [14]. Their argument was that with rising credit risk, more loans will not be paid by debtors and this will reduce bank profit. This finding was contradicted by Akhavein [15]. They found that bank size has a positive and significant effect on bank profits; hence, increasing bank size is an optimal strategy for banks to increase profits. Miller reported that credit risk reduces bank profit [16].

Second, external measures can be defined as external environmental variables that associate with bank operations. These variables include: market concentration and conditions (i.e., share returns, share prices etc.), ownership status, industry size and the macroeconomic environment. Berger stated that bank profitability has no relationship with market concentration [17]. This contradicts the earlier 
findings by Molyneux [18]. In the work. market concentration has a positive and significant relationship with bank profitability. Studies are abound on the ownership and profitability of banks. Studies that advocated weak relationships include $[18,19]$. Studies on risk exposure and use of performance indices are limited in the literature.

The major challenge of using profitability as a measure of performance is that it ignores the cost of equity, which is the cost that relates to the equity available to banks. The cost of equity also reflects the market value and has been a substantial part of the operating cost with huge impact on performance. Only returns that exceed the cost of equity are beneficial to stakeholders [20]. This shows how important the cost of equity is. Again, it ignores the agency problem. Studies have shown that the agency problem affects earnings and top management tries to rectify this [21,22]. With these profitability shortcomings, a study that uses a computed performance index is thereby suitable and welcome research. This paper computed the performance index using the sortino index [21]. The sortino index is a single index performance indicator. The sortino index provides an appropriate performance benchmark. It is also considers the cost of equity in which the internal measures of profitability are literally ignored.

\subsection{Electronic Payment Channels-Forms, Costs and Benefits}

In 1990, Humphery and Berger made an early attempt to estimate the payment instrument costs, using a 1987 data set [10]. They estimated the private and social costs of nine instruments ranging from cheques, traveler's cheques, wire transfer, point of sale, automated clearing house transfers, money orders, cash, ATM bill payments and bill payments. Their findings show that cash is the cheapest payment instrument from social cost perspective while Automatic Clearing House (ACH), POS bill payment and ATM bill payment follows. However, cheque is the cheapest method of payment from the private perspective, followed by cash, $\mathrm{ACH}$ and $\mathrm{POS}$ bill payment.

Kolawole found that there was a considerable decline in the value of cheques between 1987 and 1993 [8], and this was due to decline in interest rates and turnaround improvement in the processing of cheques. However, the usage of cheques did not decline despite the decline in the value of float; rather, it increased by $20 \%$. Consequently, the author raised a critique on the hypothesis of Humphrey and Berger that explains the use of cheques. Gul [23] studied how Norwegian banks process various payment instruments and determine their cost element. Instruments used include: cheque, payment cards (consisting of ATMs and POS), and electronic giro. They found that indirect cost such as personnel costs, the cost of buildings, computer system operations and marketing and office supplies are allocated across all payment systems and thus increase overall costs. They conclude that the paper-based payment system (physical cash) is more costly than electronic approaches.

Kolawole [8] examined the benefit of adopting card to pay for activities. This was performed by substituting the general-purpose card for proprietary retailer cards. It was found that it was convenient to use a single payment card which has the potential to earn more rebates. Ma [13] proposed three factors determining private use of electronic banking, including consumer wealth, convenience and personal involvement. Other factors considered were security, privacy, budgeting, control and transaction-specific factors (i.e., variable amount bill versus fixed amount), and transaction size.

\subsection{Adoption of Electronic Payment Channels in Nigeria}

The electronic payment instruments consist of the ATM, POS, mobile money and internet banking, among others. Payment activities on these channels are sponsored by deposit money banks in Nigeria with support from FinTech companies such as Visa international, Master Card Incorporation, Interswitch company etc. End users use the card to facilitate transactions on ATM and POS terminals. The adoption was quite impressive, as it grew from inception (see Table 1). Kolawole [8] state that cultural uncertainty avoidance are activities that reduce ambiguity and are such perceived to be valuable. Veiga [24] proclaimed that electronic payment platforms provide this kind of service for commercial banking end users through their numerous services. 
Nigeria's payment channel transaction approaches an all-time record of N86.1 trillion in 2017 as reported by the National Bureau of Statistics. This is an approximately $32 \%$ rise above the total transaction value in 2016 (N65.1 trillion). The report supported the choice of electronic payment channels, as it pointed out clearly that the major electronic payment channels adopted by end users in 2017 were POS, mobile money, ATM and online banking.

Based on the reviewed literature, the contribution of this paper are as follows: (i) it explores the effect of electronic payment technology innovation on bank performance in emerging economies through new evidence; (ii) it uses a new measure of performance-the single index performance indicator-which is innovative to empirical research in this regard; (iii) it provides emerging economies with the mechanism of impact of payment technology on market risk exposure, which has not been used in the literature on emerging economies and lastly; (iv) it provides sound policy recommendations for payment technology and financial sector integration in emerging markets.

\section{Methods}

The section consists of the sample area, model specification and methods, and preliminary results.

\subsection{Sample}

The sample consists of the fourteen [12] deposit money banks listed on the Nigerian Stock Exchange Market. The study period ranged from 2012 to 2017, respectively. The study period is justifiable on two grounds: on the one hand, the cashless policy that heralded the beginning of the development of payment technology in Nigeria was brought to bear in 2012. On the other hand, there is no available national data on electronic payment technologies for Nigeria before 2012; hence, unavailability of data. This paper used quarterly data for the number of samples required. The performance index was estimated using the sortino index. The sortino index is the process of expressing the sortino ratio in percent. The sortino ratio is a single index performance indicator that has a minimum acceptable return i.e., any return below the minimum acceptable return will discourage investors from investing. This paper follows the $1 \%$ daily acceptable changes in return as the minimum acceptable return. The risk exposure is estimated using the downside risk measure. In order to downside the risk, this paper generated the traditional risk series using the standard deviation of the market value of each of the banks. Afterwards, this paper concentrated on the $5 \%$ acceptable daily changes in equity return as stipulated by the Security and Exchange Commission rule in 2012. Therefore, the probability of risk associated with the equity trading risk is $5 \%$. The market value data was extracted from the Nigerian Stock Exchange, performance index and risk exposure were computed by the author, the volume of electronic payment transactions was sourced from the Nigerian Inter-Bank Settlement System (NIBSS) database and the Central Bank of Nigeria. In total, this paper worked with 336 observations, which consisted of the 14 listed deposit money banks on the Nigerian exchange for six years. In this paper, the value of electronic payment technology transactions are the regressors, while performance index and risk exposure variable are the regressands.

\subsection{Classification of Variables}

This paper classifies variables as regressand and regressor variables.

\subsubsection{Regressand (Dependent) Variables}

Based on the scope, this paper makes use of two regressands, namely the performance index and the risk exposure variable. Studies have used profitability ratios such as return on asset (ROA) and return on equity $(\mathrm{ROE})$ as a measure of performance $[23,25,26]$. Other measures adopted by existing studies include profits and economic value added (EVA) among others [27-29]. Conversely, this study used the sortino index, which is a single index performance indicator. Adopting the sortino index to measure performance is rare in the literature, however, it is more important to use a better measure 
than to depend only on company characteristics like ROA and ROE etc. The sortino index is computed as follows:

$$
\text { Sortino Index }=\frac{E\left(R_{\text {banks }, i, t}\right)-M A R}{\sqrt{\frac{1}{T}} \sum_{\substack{t=0 \\ R \prec M A R}}\left(R_{\text {banks, } R<1 \%}-M A R\right)^{2}}
$$

Note: Market returns of selected banks $(R)$ Return of the market $(M A R)$, Total number of observation $(T)$. The risk exposure is measured as the downside of the associated risk to bank stock returns. This paper calculated the traditional risk series through the standard deviation and considers every point that the risk is beyond the acceptable $5 \%$ change. At any point that the downward swing is deeper than $5 \%$, this paper estimates a $5 \%$ change return and used that against the actual value [30].

To account for the suitability of the explanatory variables, this study estimated the time varying dynamic correlations (DCC) between performance index and risk exposure index [31]. This study ascertains the cross correlation between the two explanatory measures. The DCC model assumes that the conditional variance of each variable follows the Generalized Autoregressive Conditional Heteroskedasticity (GARCH) process in Equation (2):

$$
h_{t}=\partial+\alpha \varepsilon_{t-1}^{2}+\beta h_{t-1}
$$

where $\partial=\left[\partial_{1}, \ldots, \partial_{m}\right]^{\prime}, \alpha=\left[\alpha_{1}, \ldots, \alpha_{m}\right]^{\prime}$, and $\beta=\left[\beta_{1}, \ldots, \beta_{m}\right]^{\prime}$ Engle [31] proposed that the conditional correlations are time-varying and specified the dynamic correlation model as follows.

$$
H_{t}=D_{t} R_{t} D
$$

where $R$ is the correlation matrix containing time varying conditional correlations and therefore, $R$ is time varying. The diagonals of $R$ and $D$ are:

$$
R=\operatorname{diag}\left[q_{11, t}^{-1 / 2}, \ldots, q_{M M, t}^{-1 / 2}\right] \text { and } D_{t}=\left(\operatorname{diag}\left[\operatorname{vecd}\left(H_{t}\right)\right]\right)^{\frac{1}{2}}=\operatorname{diag}\left[h_{11, t}^{1 / 2} \ldots, h_{M M, t}^{1 / 2}\right]
$$

The $M x M$ symmetric positive definite matrix is given by:

$$
H_{t}=\left(1-\theta_{1}-\theta_{2}\right) \bar{H}+\theta_{1} \varepsilon_{t-1}^{2}+\theta_{2} H_{t-1}
$$

where, $H_{t}=\left[q_{i j, t}\right], \bar{H}$ is the MxM unconditional variance marix of $\varepsilon_{t}$, and $\theta_{1}, \theta_{2}$ are the non-negative scalar parameters satisfying the following condition $\theta_{1}+\theta_{2}<1$. The (16) correlation coefficient can then be specified as follows.

$$
\rho_{i, j, t}=\frac{q_{i, j, t}}{\sqrt{q_{i, i, t} q_{j, j, t}}} \equiv \frac{\left(1-\theta_{1}-\theta_{2}\right) q_{12}+\theta_{1} \varepsilon_{1, t-1} \varepsilon_{2, t-1}^{\prime}+\theta_{2} q_{12, t-1}}{\sqrt{\left\{\begin{array}{l}
\left(1-\theta_{1}-\theta_{2}\right) \widehat{q}_{11}+\theta_{1} \varepsilon_{1, t-1} \varepsilon_{1, t-1}^{\prime}+\theta_{2} q_{11, t-1} \\
\left.\left(1-\theta_{1}-\theta_{2}\right)\right)_{22}+\theta_{1} \varepsilon_{2, t-1} \varepsilon_{2, t-1}+\theta_{2} q_{22, t-1}
\end{array}\right\}}}
$$

where, $\rho_{i, j, t}$ is the correlation coefficient at time $t$.

\subsubsection{Regressors (Explanatory) Variables}

The deposit money banks offer several kinds of electronic payment platforms to address customer payment needs. Of all these platforms, the grossly used platforms consist of the Automatic Teller Machine (ATM), Point of Sale (POS), Mobile Money Transfer (MMT) and the internet services (Web). E-payment technologies have become more important in bank payment services in Nigeria. The term 'electronic payment technologies' is measured in this paper as the total value of payments 
transacted through the payment transaction platforms, gateway payment and inter-account transfers, among others.

\subsection{Model Specification and Methods}

The standard static model with $i=1, \ldots, N ; t=1, \ldots, T$ is

$$
Y_{i t}=\alpha_{0}+X_{i t} \alpha+\varepsilon_{i t}
$$

$X_{i t}$ is a K-dimensional vector of explanatory variables, which include values of ATM transactions and POS technology transactions, total value of mobile money transfers, and value of online payment transactions. It also consists of control variables such as: values of Instant payment NIPS and National Electronic Fund Transfer (NEFT) and value of cheque services. This paper used the panel least square method to estimate the coefficients which measures the impact of electronic payment variables on bank performance and bank risk exposure. In Equation (6), $T$ is the total number of observations (2012-2017), $X_{i t}$ consists of regressors, which include the value of transaction of ATM, POS, MMT and online banking performed within this period. The error term is the time-varying idiosyncratic error and $\alpha_{0}$ is the intercept that varies over the sample area of this study. We also include the interacting dummies to examine the 'without effects' of electronic payment channels. The without effects show the behavior of bank performance without the adoption of considered electronic payment channels in Nigeria.

\section{Results}

\subsection{Descriptive Statistics}

Table 2 shows the descriptive statistics and normality tests of the explanatory variables, namely: performance index, risk exposure and profitability measure. From the table, apart from the fact that the profit measure trend is negatively skewed, it portends a higher risk. The three measures were normally distributed as indicated by the normality test. The time dimensional estimations are reported in Table 3.

Although the risk associated to the electronic payment system is much more prevalent compared to the previous cashless system, the relative impact of time is much higher in the profit measure than other performance. This indicates that profitability as a measure of performance of a bank is strongly affected by time. Meanwhile, the performance index and the risk exposure were lowly affected. After considering one period backward, the trend of the performance index is the only measure that proves significant. This shows that the trend of the performance index possesses reasonable time trend. The result of the dynamic correlation also buttressed the fact that the performance index has a better relationship with other explanatory variables considered by this paper.

Table 2. Descriptive Statistics.

\begin{tabular}{cccc}
\hline Details & Profit Measure (N' Million) & Performance Index (in \%) & Risk Exposure (in \%) \\
\hline Average & $15,259.10$ & 2.57 & 0.05 \\
Median & $10,903.00$ & 2.09 & 0.07 \\
Risk & 8.79 & 1.54 & 0.085 \\
Skewness & -0.458 & 1.44 & 0.074 \\
Kurtosis & 6.97 & 4.63 & 0.062 \\
\hline \multicolumn{5}{c}{} \\
\hline Jarque-Bera & 60.57 & Normality Test \\
Prob. Value & 0 & 2.952 & 0.079 \\
No. of Obs. & 336 & 0 & 0 \\
\hline
\end{tabular}


Table 3. Bank Performance Measures and Time Dimensions.

\begin{tabular}{cccc}
\hline Parameters & $\operatorname{Pr}_{t}$ & $\mathbf{P e}_{t}$ & $\mathbf{R e}_{t}$ \\
\hline $\begin{array}{c}\text { Sensitivity Estimate (Beta) } \\
\text { T-Stats }\end{array}$ & 5.04 & 1.29 & 0.02 \\
$p$-Value & 2.126 & 2.824 & 2.225 \\
\multicolumn{4}{c}{ One Period Lag } \\
\hline Sensitivity Estimate (Beta) & 0.043 & 0.041 & 0.058 \\
T-Stats & 0.835 & 1.07 & 0.014 \\
$p$-Value & 0.405 & 0.049 & 0.255 \\
\hline
\end{tabular}

Source: Compiled by the author. Underlying data are sourced from various annual reports of the selected deposit money banks and the Nigerian Stock Exchange Market (NSEM). The risk exposure and performance index are computed by the author. The sample period is from 2012 to 2017. Note: Pr is the profitability, Pe is the performance index, and Re is the risk exposure all at time $t$.

\subsection{Impact Assessment of E-Payment}

The characteristics of the data set were presented in Table 4. From the general review, it is obvious that the average value of the performance index is lower than the averages of other variables; this is due to the unit of measurement. In order not to have upwardly biased (If a linear-linear model specification approach is adopted then, the sensitivity beta estimates will be upwardly bias, as it trends towards the average of the profit. Hence, the double-log approach was used to specify the fifteen models estimated in this section.) sensitivity estimates, the model specification follows the double log approach. The normality test shows that all variables considered are normally distributed and therefore necessitate the adoption of the panel least square estimation technique proposed in the methodology.

Table 4. Descriptive Statistics.

\begin{tabular}{ccccccccc}
\hline Details & PI & Cheque & ATM & POS & NEFT & Mobile & Online & NIP \\
\hline Average & 2.57 & 6.15 & 4.24 & 0.73 & 12.9 & 0.6 & 0.15 & 34.91 \\
Risk & 1.54 & 0.69 & 1.63 & 0.42 & 1.06 & 0.36 & 0.02 & 13.98 \\
Skewness & 1.44 & 0.58 & -0.043 & 0.704 & 0.626 & 0.111 & 0.05 & 0.506 \\
Kurtosis & 4.63 & 1.94 & 1.72 & 1.93 & 1.78 & 1.61 & 1.45 & 1.75 \\
\hline \multicolumn{7}{c}{ Normality Test } \\
\hline Jarque-Bera & 2.95 & 9.92 & 6.49 & 12.48 & 12.16 & 7.95 & 16.03 & 10.32 \\
Prob. & 0 & 0.006 & 0.038 & 0.001 & 0.002 & 0.018 & 0.0003 & 0.005 \\
Observations & 336 & 336 & 336 & 336 & 336 & 336 & 336 & 336 \\
\hline
\end{tabular}

Source: author's compilation; Estimation was performed using EViews 8 software (Version 8, Econometric Views, Miami, United States of America) and underlying data were extracted from Central Bank of Nigeria, annual reports of selected banks and NIBSS Statistics.

Table 5 shows the results of the effects of electronic payment platforms on bank performance. There are five models in this table. Models IA-ID are curious to examine the individual effects of the four platforms selected (ATM, POS, Mobile and Web) on profit. Model IE presents the result of the effect of a system of electronic payment (i.e., cashless system) on profit. The model was quite insightful as it shows the interrelations and interactions among the payment platforms and performance. The focus of interpretation is on Model IE; nevertheless, comparison is made between the individual and interaction effects for consistency. 
Table 5. Panel Estimates of Model I (Dependent Variable: Performance Measure).

\begin{tabular}{|c|c|c|c|c|c|}
\hline Variable & Model IA & Model IB & Model IC & Model ID & Model IE \\
\hline Constant & $4.424^{* *}$ & -2.147 & $-1.927^{* *}$ & $-0.831 *$ & $1.029^{* *}$ \\
\hline t-stats & 2.049 & -0.511 & 2.858 & -2.416 & 2.944 \\
\hline Prob. & 0.048 & 0.61 & 0.037 & 0.056 & 0.034 \\
\hline ATM & $-6.648^{* *}$ & & & & $-1.046^{* *}$ \\
\hline t-stats & -2.075 & & & & 2.649 \\
\hline Prob. & 0.049 & & & & 0.028 \\
\hline POS & & $2.541^{* *}$ & & & $6.091 * *$ \\
\hline t-stats & & 3.075 & & & 2.132 \\
\hline Prob. & & 0.039 & & & 0.046 \\
\hline Mobile & & & -3.858 & & $4.796^{* *}$ \\
\hline t-stats & & & -0.075 & & 2.091 \\
\hline Prob. & & & 0.939 & & 0.042 \\
\hline Online & & & & $1.201 * *$ & $4.24^{* *}$ \\
\hline t-stats & & & & 2.132 & 2.649 \\
\hline Prob. & & & & 0.042 & 0.039 \\
\hline \multicolumn{6}{|c|}{ Control Variables } \\
\hline Cheque & & & & & $3.356^{* *}$ \\
\hline t-stats & & & & & 2.349 \\
\hline Prob. & & & & & 0.037 \\
\hline NEFT & & & & & -5.25 \\
\hline t-stats & & & & & -0.995 \\
\hline Prob. & & & & & 0.291 \\
\hline NIP & & & & & $2.666^{* *}$ \\
\hline t-stats & & & & & 2.305 \\
\hline Prob. & & & & & 0.047 \\
\hline \multicolumn{6}{|c|}{ Diagnostic Tests } \\
\hline R-Squared & 0.181 & 0.116 & 0.138 & 0.187 & 0.228 \\
\hline Adjusted R & 0.139 & 0.104 & 0.114 & 0.162 & 0.216 \\
\hline F-Statistics & 20.564 & 17.561 & 10.52 & 18.43 & 35.29 \\
\hline Probability & 0.062 & 0.04 & 0.047 & 0.059 & 0.021 \\
\hline
\end{tabular}

Source: author ompilation. The computation was performed through E-views 8. Underlying data set was garnered from the Central Bank of Nigeria (CBN) Banks' Annual Reports of several years. This model represents the major estimates with the performance measure (sortino index) as the dependent variable. The sampled period is from 2012 to 2017. ' $\mathrm{M}$ ' represents the models and their extensions. Note: the acceptance range varies from $90 \%\left({ }^{*}\right), 95 \%\left({ }^{* *}\right)$ and $99 \%$.

The result indicates that operation of an ATM has been a deterrent to the performance level of banks. This is evidenced with the negative effects observed in both the individual and interaction models. In both models, the negativity was highly significant, which implies that the physical mounting of the ATM machines and cost of building of ATM locations are significant and reduce the performance of banks. This result is in line with the findings of [32,33]. In the work of Kashif [32], the cost of erecting the ATMs constitutes a large amount in the investment activity of the income statements of banks in Pakistan. Uchechukwu [33] reported a negative relationship between the cost of building ATM locations on bank profit and tangibility. The reason they alluded to the negative relationship is that banks use ATMs to gain large coverage and this increases their expenses on an annual basis and further cuts down profit level. The negative effect found by this study is attributed to the annual increase in investment spending as a result of the high cost of building up an ATM stand.

The point of sale (POS) has an increased effect on the performance of banks on the exchange. An increase in the use of POS machines raises the visibility and coverage of banks. This can be seen in the individual and interaction effects, as both effects gave positive signals (see Table 5). The coefficients of the regressor in the two models (Models IB and IE) were significant at $95 \%$ confidence levels. Intuitively, the positive effects indicate that investment in the POS has an increasing effect on the performance of banks through visibility of the exchange. This finding supports the claims of [34-36]. Yomere [36] relate the use of POS to income. It found that rising use of POS generates high income at a 
benefit to banks. The major reason offered is that the cost associated with providing POS services is lower than that of ATMs. This reason was also shared by this study.

Mobile Money Transfer (Mobile) is another electronic payment platform that was given high priority by this study. On one hand, the interaction effect shows that the advent of mobile banking has brought positive effects on bank performance. The implication is that mobile banking increases banking transactions performed by users and has generated increased profits and performances of banks in the stock exchange. The coefficient was statistically reliable for policy formulation as shown by the confidence level of $95 \%$. On the other hand, the individual effect was negative. The coefficient of the individual effect in this case was not significant and such an estimate is not reliable. Hence, the thrust of the effect is the interaction effect. Varying impacts were observed in the literature and this buttressed our findings in both models. For instance, Ene [35] found a negative relationship between mobile banking and bank performance through profit. The result to them is as a result of the increasing number of unsuccessful transactions, which discourage individuals from using the medium. Meanwhile, in the work of [36], they found a positive effect between mobile money transfer and bank profit vis-à-vis development of the banking sub-sector. In Pakistan, Kashif [32] also found a positive relationship between Mobile and bank profits. However, the measure of profit in their work was the return of equity (ROE).

The Online (Web) medium of electronic payments has increasing effects on bank performance. This is proofed, given the positive signals seen in both the individual and interaction models. The coefficients were reliable for policy formulations. Meanwhile, the online method will produce more returns to banks and bank shareholders when used alongside all other e-payment platforms, as the coefficient of the interaction model is greater than that of the individual model. Studies with positive impact between the online platform and bank performance through profit include $[26,33,37]$ and studies with negative findings include [35,38]. The reason offered by studies with negative effects is high rates of bank charges which discourage customers to use this method. Conversely to recent studies, this study inclusive, positive effects were found which suggests that this is due to a reduction in the cost of operating an online banking system. It also offers larger coverage, which brings about the possibility of banking the unbanked populace.

This study also makes provisions for control variables in the interaction model (Model IE). The control variables include cheque, NEFT and NIP. The results show that the use of cheque and NIP e-payment platforms has a positive effect on bank profit. Other diagnostic tests considered show that our models are strong, reliable and correctly specified. For instance, R-squared and adjusted R-squared ranges between $11 \%$ and $22.8 \%$. This shows that there are other factors that determine bank performance. At $22.8 \%$, it implies that the payment aspect of banking activities is quite substantial in banking operations in Nigeria.

\subsection{Robustness Checks}

This study performed robustness tests on the consistency of the parameters estimated in two ways. Firstly, an estimate of alternative specification by using profit as a measure of performance and including slope dummies among the explanatory variables. Secondly, bank risk exposure to the equity market as a measure of bank performance. The result of the first approach is presented in Table 6, while that of the second approach is in Table 7.

In Table 6, the coefficients of ATM that serve as a measure of the effect of ATM operations on bank performance have a complete sign change in the individual model but retain the negative effects in the interaction model. POS retain its positive effects in both models. Furthermore, mobile portends a similar sign change with POS, as the sign retains negative and positive values in both individual and interaction models. The online method also had positive effects in both models and the signs were retained when compared to the original models.

The results in the lower panel of Table 6 represents the interaction dummies included in the model for alternative specification. The results show that even with interactions with dummies, the 
coefficients of the original estimates remain strong to model specification, except for ATM, whichhas a complete reversal of signs. The positive effect in the ATM coefficient indicates that in specific future periods, increasing ATM operations will improve the performance of banks through an increase in the profit level of Nigerian banks. The dummy included in the interaction model gave a positive sign and was significant at 0.041 . This confirms that electronic payment has positive effect on Nigerian bank performance. That is, if the banks decide to expand the coverage through an electronic payment option, then the banks are expected to earn more profit in return.

Table 6. Robustness Through Change in Specification Model II (Dependent Variable: Profit).

\begin{tabular}{|c|c|c|c|c|c|}
\hline Variable & Model IIA & Model IIB & Model IIC & Model IID & Model IIE \\
\hline Constant & $-6.941 * *$ & $-4.723 * *$ & $4.717 *$ & $3.746 *$ & $4.39 * *$ \\
\hline t-stats & 2.264 & -0.246 & 1.936 & 2.116 & 3.477 \\
\hline Prob. & 0.049 & 0.806 & 0.052 & 0.057 & 0.028 \\
\hline ATM & $2.137^{* *}$ & & & & $-1.977^{* *}$ \\
\hline $\mathrm{t}$-stats & 5.009 & & & & -2.017 \\
\hline Prob. & 0.016 & & & & 0.048 \\
\hline POS & & $1.645^{* *}$ & & & $2.42 * *$ \\
\hline t-stats & & 2.705 & & & 2.17 \\
\hline Prob. & & 0.402 & & & 0.04 \\
\hline Mobile & & & -7.559 & & 1.346 \\
\hline t-stats & & & -0.122 & & -1.895 \\
\hline Prob. & & & 0.904 & & 0.137 \\
\hline Online & & & & $1.041^{* *}$ & $1.371^{* *}$ \\
\hline t-stats & & & & 2.072 & 2.082 \\
\hline Prob. & & & & 0.044 & 0.049 \\
\hline \multicolumn{6}{|c|}{ Interacting Dummies } \\
\hline DUMMIES@ATM & $1.65^{* *}$ & & & & \\
\hline t-stats & 2.272 & & & & \\
\hline Prob. & 0.047 & & & & \\
\hline DUMMIES@POS & & $1.283^{* *}$ & & & \\
\hline t-stats & & 2.545 & & & \\
\hline Prob. & & 0.045 & & DUMMIES@WEB & DUMMIES@ALL \\
\hline DUMMIES@MOBILE & & & 2.035 & $2.027 * *$ & $1.344 * *$ \\
\hline t-stats & & & 0.936 & 2.209 & 2.398 \\
\hline Prob. & & & 0.351 & 0.043 & 0.041 \\
\hline \multicolumn{6}{|c|}{ Diagnostic Tests } \\
\hline R-Squared & 0.111 & 0.145 & 0.983 & 0.092 & 0.204 \\
\hline Adjusted R & 0.101 & 0.116 & 0.816 & 0.087 & 0.185 \\
\hline F-Statistics & 9.524 & 6.844 & 4.403 & 10.435 & 17.53 \\
\hline Probability & 0.059 & 0.061 & 0.069 & 0.048 & 0.037 \\
\hline
\end{tabular}

Source: author's compilation. The computation was performed through E-views 8. Underlying data set was garnered from the Central Bank of Nigeria (CBN), Banks' Annual Reports of several years. This robustness check estimate was performed with several extensions. The dependent variable here is profit (annual profit of the deposit money banks). The sampled period is from 2012 to 2017. 'M' represents the models and their extensions. Note: the acceptance range varies from $90 \%\left(^{*}\right), 95 \%\left(^{* *}\right)$ and $99 \%$.

Here, the study adopted another measure of performance (risk exposure to stock market); this practice is not peculiar to this study. The return on equity has been used as a measure of profit by previous studies $[26,34,35,37,38]$. From the result, the electronic payment platforms considered in this study are consistent to change in measure of dependent variable, as most coefficients for the regressors retained their respective signs (except for ATM which shows a slight reversal in sign in the interaction model). This specifically shows that the original model is reliable for policy formulation as it is consistent to changes in model specification and explanatory variables. It can be deduced intuitively that the electronic payment option that serves as one of the instruments of a cashless system enhances the performance of Nigerian deposit money banks. 
Table 7. Robustness Through Volume of Activities Model III (Dependent Variable: Risk Exposure).

\begin{tabular}{|c|c|c|c|c|c|}
\hline Variable & Model IIIA & Model IIIB & Model IIIC & Model IIID & Model IIIE \\
\hline Constant & $2.176^{* *}$ & $-7.454^{* *}$ & $4.695^{* *}$ & -1.116 & $3.036^{* *}$ \\
\hline t-stats & 2.404 & -2.355 & 2.169 & -0.621 & 2.188 \\
\hline Prob. & 0.036 & 0.043 & 0.046 & 0.536 & 0.046 \\
\hline ATM & $-1.345^{* *}$ & & & & $1.159 * *$ \\
\hline t-stats & -2.752 & & & & 2.289 \\
\hline Prob. & 0.037 & & & & 0.041 \\
\hline POS & & $1.596^{* *}$ & & & $3.119 * *$ \\
\hline t-stats & & 2.404 & & & 2.032 \\
\hline Prob. & & 0.028 & & & 0.046 \\
\hline Mobile & & & $1.039^{* *}$ & & $1.542^{* *}$ \\
\hline t-stats & & & 2.407 & & 1.071 \\
\hline Prob. & & & 0.042 & & 0.287 \\
\hline Online & & & & $-6.406^{* *}$ & $3.043^{* *}$ \\
\hline t-stats & & & & -2.404 & 2.189 \\
\hline Prob. & & & & 0.047 & 0.043 \\
\hline \multicolumn{6}{|c|}{ Control Variables } \\
\hline Cheque & & & & & 1.601 ** \\
\hline t-stats & & & & & 2.205 \\
\hline Prob. & & & & & 0.046 \\
\hline NEFT & & & & & -7.175 \\
\hline t-stats & & & & & -0.439 \\
\hline Prob. & & & & & 0.667 \\
\hline NIP & & & & & 1.981 \\
\hline t-stats & & & & & 1.169 \\
\hline Prob. & & & & & 0.245 \\
\hline \multicolumn{6}{|c|}{ Diagnostic Tests } \\
\hline R-Squared & 0.106 & 0.096 & 0.18 & 0.158 & 0.183 \\
\hline Adjusted R & 0.101 & 0.092 & 0.168 & 0.143 & 0.157 \\
\hline F-Statistics & 10.403 & 8.564 & 8.564 & 16.51 & 15.4 \\
\hline Probability & 0.01 & 0.058 & 0.062 & 0.048 & 0.039 \\
\hline
\end{tabular}

Source: author compilation. The computation was performed through Eviews 8. Underlying data set was garnered from the Central Bank of Nigeria (CBN), Banks' Annual Reports of several years. This robustness check estimate was performed with several extensions. The dependent variable here is risk exposure (the risk exposure is estimated using the standard deviation of the market price of the selected deposit money banks. This is conducted with a 5\% threshold to downsize the market risk). The sampled period is from 2012 to 2017 . ' $\mathrm{M}$ ' represents the models and their extensions. Note: the acceptance range varies from $95 \%(* *)$.

\section{Discussion and Conclusions}

The inferential methodology was conducted using the panel least square approach and follows autoregressive and distributional lag modelling. The findings show that the performance of banks increased after the introduction of electronic payment systems into the financial sector. More so, the inferential results show that performance of banks contradict the autoregressive and distributional lag modelling frameworks. The implication of this is that bank performance in the current period does not depend on previous performances, and that investors need not to worry about the current circumstances of the bank's performance as a result of poor previous bank performance. However, what are paramount in determining the performance of banks are the resources available for banks to maximize operations in the current time period. That is central to estimating the expected profit of banks in Nigeria.

This study investigates the effects of electronic payment platforms on bank performance. To broaden the curiosity, this study identified four major electronic payment platforms, which include ATM, POS, Mobile Money and Online Banking. These four e-payment channels have increasing effects on the performance of banks, as reported by several estimations. Intuitively, the results suggest that banks can increase performance and minimize their risk exposure to the stock market by promoting the use of electronic payment channels, especially POS, Mobile Money and Online Banking activities. The reason for this intuition is that these channels are cost effective and have wider coverage compared 
to other e-payment channels in Nigeria. More so, the ability of these channels to bank the unbanked populace is highly significant and more cost effective. Hence, banks should focus on developing these three channels so as to maximize the benefit of the electronic payment system.

This study concludes on two grounds. First, investors do not need to be concerned about the behavior of previous performances of banks. However, what is more protuberant is the current amount of resources available to the bank to meet their current commitments. Also, it is noticeable from the trends of bank profits that the electronic payment system has been favorable to banks in terms of profit and minimizing risk exposure. Therefore, it is important for the management of banks to consider investing in electronic payment channels identified by this paper, as it increases the strategies available to maximize profits and enhance performance.

Second, the average effects of all electronic payment channels used by this paper continuously increase bank profits levels, even after controlling for specification and other measures of performance. The results are an indication that one of the strategies that banks in Nigeria (especially deposit money banks) can adopt to enhance their tangibility and performance is to promote the use of electronic payment channels. The increasing effects of these e-payment channels subscribe to the conclusion that electronic payment systems have increased bank performance from inception.

Finally, deposit money banks that have the intention to increase performance in the short to medium term should do so by effectively utilizing the cashless instruments such as electronic payment channels; specifically, the online channel, MMT and POS technologies. Furthermore, more concentration should be given to electronic payment channels to stimulate financial inclusion in Nigeria.

\subsection{Operational and Policy Implication}

Based on the findings, the following recommendations are made for policy implications. The recommendations start from the shareholders and prospective investors in banking stocks; this is followed by specific recommendations.

i Shareholders and prospective investors should concentrate on the resources (operational, financial and managerial) that the bank possessed in the current period. Less emphasis should be placed on previous performances made by the respective deposit money banks.

ii The government should examine the charges made by banks on online and mobile money payment transactions. These charges must be moderated to enable increased inclusion in the financial sector, as findings show that it is relatively high and discourages customers from using such electronic payment channels.

iii Banks should shower more investment in the provision of the POS electronic payment channel, as this will heighten their profit and performance in the short to medium term.

iv Since MMT and online payment channels are more cost effective, this study recommends that banks should increase the provision of these mediums and monetary authorities such as the Central Bank of Nigeria should monitor transactions on these platforms so as to reduce the risks associated with online transactions.

$\mathrm{v}$ This study recommends that deposit money banks should improve on the awareness given to any financial innovations, especially those that pertain to inclusiveness in the financial sector. For instance, the awareness that has been given to bank codes to make transfers among banks has resulted in an increased extent to which customers access financial services in the country.

\subsection{Limitation and Future Research}

This study has demonstrated that electronic payment systems have increasing effects on performance and profits of deposit money banks. In this connection, subsequent studies on how the electronic payment policy will benefit banks are needed. For example, other POS card acceptance services attract a significant part of bank income and thus increase investment activities of the financial 
statement. Hence, research on the impact of POS card acceptance rate on bank profitability is desirable. Again, the likely effects of internet fraud (that may become prevalent) on bank performance are other areas that are worth investigating.

Lastly, when longer observations are available on electronic payment channels, a bank-specific analysis will be more appropriate. Therefore, the estimation can be revised for improved estimations.

Funding: The publishing fee of this paper was supported by the DGIST R\&D Program of the Ministry of Science, Technology and ICT (DGIST-18-IT-01).

Conflicts of Interest: The author declares no conflict of interest.

\section{References}

1. Beck, T.; Demirguc-Kunt, A.; Maksimovic, V. Financial and legal constraints to firm growth: Does firm size matter? J. Financ. 2005, 60, 137-177. [CrossRef]

2. Beck, T.; Maimbo, S.M.; Faye, I.; Triki, T. Financing Africa: Trough the Crisis and Beyond; The World Bank: Washington, DC, USA, 2011.

3. Chang, T.; Caudill, S.B. Financial development and economic growth: The case of Taiwan. Appl. Econ. 2005, 37, 1329-1335. [CrossRef]

4. Levine, R. Finance and Growth: Theory and Evidence; NBR Working Paper; National Bureau of Economic Research: Cambridge, MA, USA, 2004.

5. Nwani, C.; Bassey Orie, J. Economic growth in oil-exporting countries: Do stock market and banking sector development matter? Evidence from Nigeria. Cogent Econ. Financ. 2016, 4. [CrossRef]

6. Uddin, G.S.; Sjo, B.; Shahbaz, M. The causal nexus between financial development and economic growth in Kenya. Econ. Model. 2013, 35, 701-707. [CrossRef]

7. Ogwumike, F.O.; Salisu, A.A. Financial development and economic growth in Nigeria. J. Monet. Econ. Integr. 2010, 12, 18-35.

8. Kolawole, O.; Mustapha, S.A. Impact of Cashless Policy on Bank's Profitability in Nigeria. An unpublished research report, 2018.

9. Hasan, I.; Malkamaki, M.; Schmiedel, H. Technology, Automation and Productivity of Stock Exchanges: International Evidence. J. Bank. Financ. 2003, 27, 1743-1773. [CrossRef]

10. Humphrey, D.; Pulley, L.B.; Vesala, J.M. Cash, Paper, an Electronic Payments: A cross country analysis. J. Money Credit Bank. 1996, 28 Pt 2, 914-939. [CrossRef]

11. Bei, W. The impact of TPP platform on commercial bank's management. J. Financ. Res. 2011, 1, 40-44.

12. Deng, I. Research on the development of TPP and banks. Decis. Manag. J. 2009, 6, 183-190.

13. Ma, Z. Research on the Cooperation Pattern between TPP Companies and Other Business. Ph.D. Dissertation, Capital University of Economics and Business, Beijing, China, 2005.

14. Berger, A.N.; Hanweck, G.A.; Humphery, D.B. Competitive viability in banking: Scale, scope and product mix economies. J. Monet. Econ. 1987, 20, 501-520. [CrossRef]

15. Akhavein, J.D.; Berger, A.N.; Humphrey, D.B. The Effects of Megamergers on Efficiency and Prices: Evidence from a Bank Profit Function; Finance and Economic Discussion Series 9; Board of Governors of the Federal Reserve System: Washington, DC, USA, 1997.

16. Miller, S.M.; Noulas, A.G. Portfolio mix and large-bank profitability in the USA. Appl. Econ. 1997, 29, 505-512. [CrossRef]

17. Berger, A.N. The profit structure relationship in banking: Tests of market-power and efficient structure hypothesis. J. Money Credit Bank. 1995, 27, 404-431. [CrossRef]

18. Molyneux, P.; Thorton, J. Determinants of European bank profitability: A note. J. Bank. Financ. 1992, 16, 1173-1178. [CrossRef]

19. Bourke, P. Concentration and other determinants of bank profitability in Europe, North America and Australia. J. Bank. Financ. 1989, 13, 65-79. [CrossRef]

20. Kyriazis, D. Anastassis, C. The validity of the economic value added approach: An empirical application. Eur. Financ. Manag. 2007, 13, 71-100. [CrossRef]

21. Atik, A. Detecting income-smoothing behaviours of Turkish listed companies through empirical tests using discretionary accounting changes. Crit. Perspect. Account. 2009, 20, 591-613. [CrossRef] 
22. Bikker, J.A.; Metzemakers, P. Bank provisioning behaviour and procyclicality. J. Int. Financ. Mark. Inst. Money 2002, 15, 141-157. [CrossRef]

23. Gul, S.; Irshad, F.; Zaman, K. Factors affecting bank profitability in Chinese banking. J. Econ. Forecast. 2011, $14,61-87$.

24. Veiga, J.F.; Floyd, S.; Dechant, K. Towards Modeling the effects of National Culture on it Implementation and Acceptance. J. Inf. Technol. 2011, 16, 145-158. [CrossRef]

25. Olson, D.; Zoubi, T.A. Efficiency and bank profitability in MENA countries. Emerg. Mark. Rev. 2011, 12, 94-110. [CrossRef]

26. Osazevbaru, H.O.; Sakpaide, E.J.; Ibubune, R.O. Cashless policy and banks' profitability in Nigeria. Eur. J. Account. Audit. Financ. Res. 2014, 2, 1-12.

27. Heffernana, S.A.; Fu, X. Determinants of financial performance in Chinese banking. Appl. Financ. Econ. 2011, 20, 1585-1600. [CrossRef]

28. Jackson, A. The how and why of EVA at CS First Boston. J. Appl. Corp. Financ. 1996, 9, 98-103. [CrossRef]

29. Zheng, X. The application of Economic Value Added on performance evaluation of listed banks in China. J. Acad. Res. Econ. 2014, 6, 103-118.

30. Mustapha, S.A. Stock (mis) Pricing and Divestment in Africa; African Development Bank Working Paper Series, No. 258; African Development Bank: Abidjan, Côte d'Ivoire, 2017.

31. Engel, R. Dynamic Conditional Correlation: A Simple Class of Multivariate Generalized Autoregressive Conditional Heteroskedasticity Models. J. Bus. Econ. Stat. 2002, 20, 339-350. [CrossRef]

32. Kashif, M.K.; Mohammad, E.J.L. Impact of cashless banking on profitability: A Case study of banking industry of Pakistan. Res. J. Commer. Econ. Soc. Sci. 2016, 10, 82-93.

33. Uchechukwu, N.; Chubuzor, E.E.; Donatus, N.; Ejeagbasi, G. Empirical Analysis of the Effect of Cashless Policy on the Performance of Banking Industry in Nigeria. IDOSR J. Humanit. Soc. Sci. 2017, 2, 93-110.

34. Asekome, M.O.; Akara, C.K. Cashless policy and commercial banks' profitability in Nigeria. Adv. Soc. Sci. Res. J. 2018, 5, 43-56.

35. Ene, E.E.; Itah, A.J. Impact of cashless banking on bank's profitability: Evidence from Nigeria. Asian J. Financ. Account. 2014, 6, 362-376.

36. Yomere, G.O.; Osazevbaru, H.O. Benefits and Challenges of Nigeria's Cash-less Policy. Kuwait Chapter Arab. J. Bus. Manag. Rev. 2015, 4, 1-10.

37. Ajayi, L.B. Effect of cashless monetary policy on Nigerian banking industry: Issues, prospect and challenges. Int. J. Bus. Financ. Manag. Res. 2014, 2, 29-41.

38. Armey, L.E.; Lipow, J.; Webb, N.J. The impact of electronic financial payments on crime. J. Inf. Econ. Policy 2014, 29, 46-57. [CrossRef]

(C) 2018 by the author. Licensee MDPI, Basel, Switzerland. This article is an open access article distributed under the terms and conditions of the Creative Commons Attribution (CC BY) license (http://creativecommons.org/licenses/by/4.0/). 